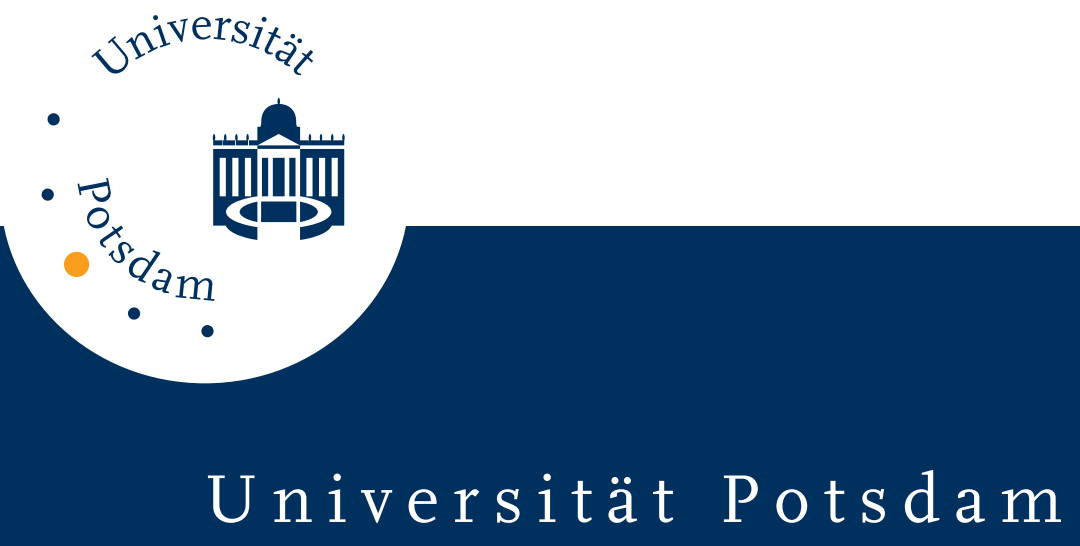

Diether Hopf

\title{
The children of aliens in West German schools: situation and problems
}

first published in:

Minorities : community and identity; proceedings of the Dahlem Workshop on Minorities / Charles Fried [Hrsg.]. - Berlin u.a. : Springer, 1983, S. 133-157

Postprint published at the Institutional Repository of Potsdam University:

In: Postprints der Universität Potsdam

Humanwissenschaftliche Reihe ; 100

http://opus.kobv.de/ubp/volltexte/2009/3637/

http://nbn-resolving.de/urn:nbn:de:kobv:517-opus-36374

Postprints der Universität Potsdam

Humanwissenschaftliche Reihe ; 100 


\title{
THE CHILDREN OF ALIENS IN WEST GERMAN SCHOOLS: SITUATION AND PROBLEMS
}

\author{
D. Hopf \\ Max-Planck-Institut für Bildungsforschung \\ 1000 Berlin 33, F.R.Germany
}

\section{GENERAL OUTLINE OF PROBLEMS AND QUANTITATIVE SITUATION}

At present, there are over 4.6 million aliens living in the FRG and West Berlin; this is equivalent to approximately $7.5 \%$ of the total population (1). Roughly three quarters of the foreign nationals originate from so-called recruitment countries, particularly Turkey, Italy, Yugoslavia, Greece, and Spain, from which workers were recruited by the FRG until 1973. It is the children of these foreign nationals who will concern us in this paper (2).

Approximately three quarters of all aliens have been living in the FRG for five years or longer, and over half of them arrived eight or more years ago. The age and family structure has shifted considerably over this period: whereas there were relatively many "guestworkers" who were unmarried or living alone 20 years ago, the proportion between men and women is now more balanced, and there is a growing number of children and young people.

In the future, the numerical proportions between Germans and aliens, particularly between German and foreign children, will shift still further, as illustrated by Fig. 1, showing the different relations between producers and nonproducers as well as the shift in the numerical proportions among children and juveniles (3). 


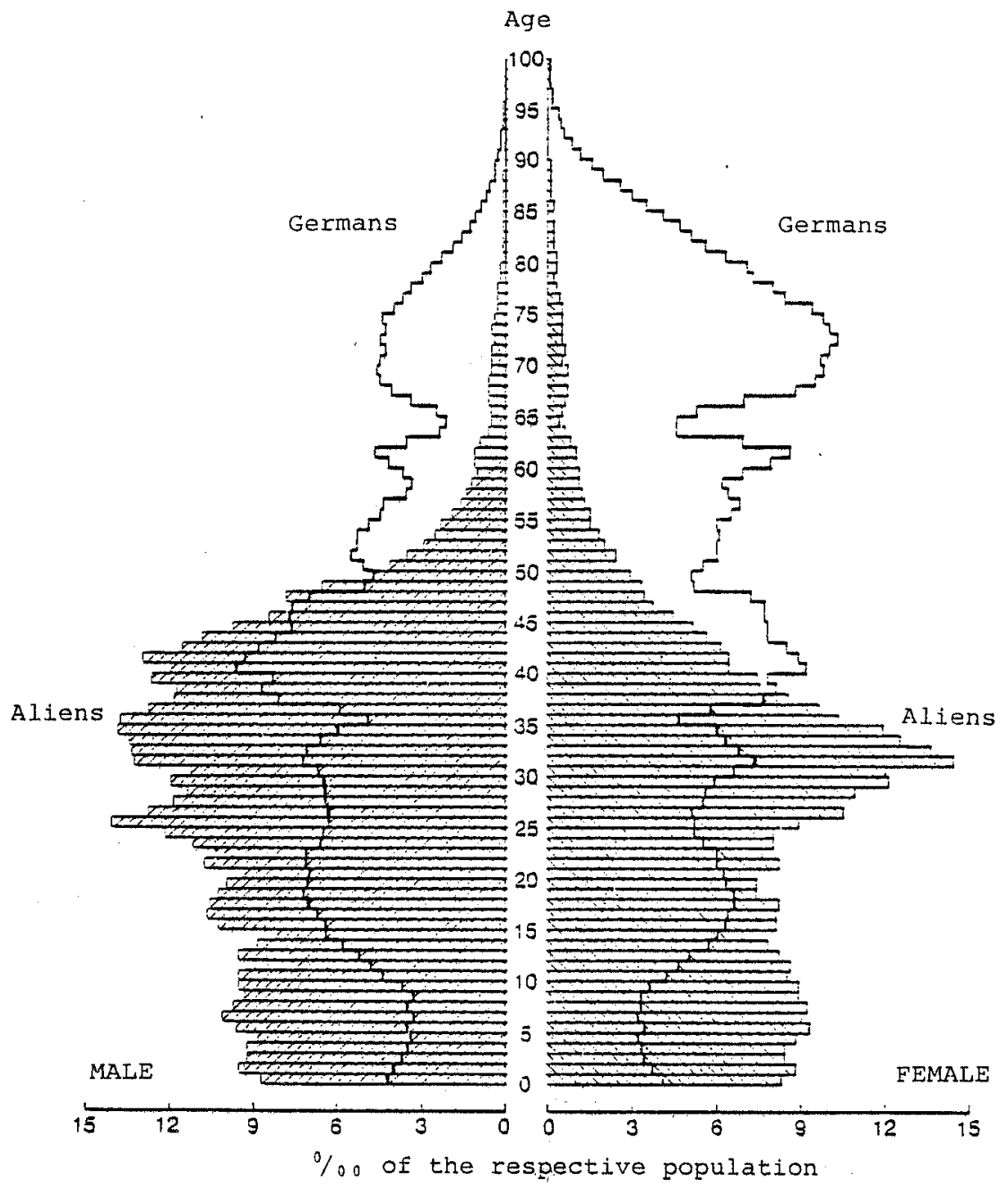

FIG. 1 - Age structure of the population of Berlin (West) as of January 1, 1982 (Germans/aliens).

The following statistics apply for the six-to-ten-year-old children of aliens in the FRG (4). 
The prognoses contained in Table 1 are mainly based on the assumed continuation of the known birth rate statistics and, for later years, on an estimation of the different reproductive rates of the German and alien populations.

It is possible that factors other than the birth rate will have greater influence on quantitative developments, for example, legislative changes with respect to aliens, which as of Oct. 1, 1978, changes residence permit conditions, the effect of which will probably be an increase in the number of children and juveniles joining their parents. For almost half of the foreign workers residing in the FRG have close family relations still living in their country of origin. An estimated 1.4 million candidates for immigration (5) (apart from those from EEC countries) could join their families in the FRG in the near future, including 700,000 children and juveniles. Of importance in this connection are government subsidies to families with children which as of January 1, 1979, are only minimal for children living in the country of origin (6).

\section{THE CHILDREN OF FOREIGN NATIONALS IN THE EDUCATION SYSTEM}

According to the statistics of the Ministers of Education and Culture Conference (Kulturministerkonferenz) of August 1982, in the school year 1981/82, 695,700 foreign children attended schools of general education in the FRG. Eighty-seven percent of these come from the following six recruitment countries: Turkey (51.5\%), Italy (11.5\%), Yugoslavia (10.4\%), Greece (7.5\%), Spain $(3.5 \%)$, and Portugal (2.7\%). The proportion of foreign pupils of the total number of schoolchildren varies according to school type. For the school year 198182 the percentages were as follows: primary school $13.3 \%$; secondary modern school 11.8\%; special schools 9.3\%; grammar school 2.1\%; secondary technical school $2.5 \%$. This unequal distribution is shown in Table 2.

These statistics show clearly that foreign children compared to Germans are underrepresented at grammar and secondary technical schools and overrepresented at secondary modern schools.

TABLE 1 - Six-to-ten-year-old children of aliens (in \% of the age group).

1977

1978

1979

1980
7.99
9.61
11.68
13.72
1981

1982

1983

1984
14.94

15.76

15.79

15.20 
TABLE 2 - Total number of German and foreign school students at general educational schools in the secondary stages I and II, school years 1981/82 (7).

\begin{tabular}{|c|c|c|c|c|c|}
\hline 1. & $\begin{array}{c}\text { Secondary } \\
\text { Modern }\end{array}$ & $\begin{array}{c}\text { Secondary } \\
\text { Technical }\end{array}$ & Grammar & $\begin{array}{c}\text { Compre- } \\
\text { hensive }\end{array}$ & Total \\
\hline $\begin{array}{l}\text { 2. German } \\
\text { Pupi1s }\end{array}$ & $1,968,058$ & $1,290,909$ & $2,062,866$ & 201,787 & $5,523,620$ \\
\hline $3 . \%$ of Total & 35.6 & 23.4 & 37.3 & 3.7 & 100 \\
\hline $\begin{array}{l}\text { 4. Foreign } \\
\text { Pupi7s }+\end{array}$ & 202,230 & 25,107 & 22,612 & 18,465 & 268,414 \\
\hline $\begin{array}{l}\text { 5. \% of Tota1 } \\
\text { of Foreign } \\
\text { Children }+\end{array}$ & 75.3 & 9.4 & 8.4 & 6.9 & 100 \\
\hline
\end{tabular}

${ }^{+}$from recruitment countries

These average figures for the whole of the FRG conceal the fact that there are considerable regional differences. For example, the quota of foreign pupils attending special schools (of all pupils in special schools) in the FRG in the school year 1981/82 totalled $9.3 \%$, but the extremes ranged from $18.5 \%$ in Baden-Würtemberg to $3.8 \%$ in Schleswig-Holstein, whereby the quotas for nationals of different foreign countries varied considerably. For example, only $2.9 \%$ of the Greek pupils went to special schools as compared to $7.9 \%$ of the Italians. Also, disparities in distributions within the individual Bundesländer must be assumed. The resultant problems for schools and instruction are varied. Many obvious differences - noticeable even by a glance at the statistics cited - have not yet been explained.

An examination of the quantitative relations shows that the end of schooling is a special problem area. Considering the customary close relation in the FRG between career choice opportunities, job training and practice, and school reports and qualifications, it is important that fewer than half of the children of foreign parentage pass their final exams at secondary modern school. For example, in Bavaria in 1978, 50\% of the foreign school leavers left without certificates, and in Berlin it was $62 \%$ - compared wtih $26 \%$ of the German school leavers. The figures would appear even less favorable were they confined to the children of parents from the recruitment countries only.

The available data on the number of foreign students attending vocational schools are unsatisfactory and not very reliable (8). An approximate estimate of the proportion of foreign students at these schools is provided by Table 3 . 
TABLE 3 - Foreign school students enrolled at vocational schools.

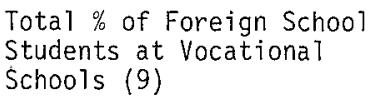

1973

1974

1975

1976

1977

1978

1979

1980
2.69

2.86

2.76

2.61

2.61

2.68

2.94

3.84
Total \% of Foreign Nationals of the Total Population of the Same Age (from 16 to under 19 years old)

Although the comparison of these age groups is a rough one, these figures show that the percentage quotas in the schools do not correspond to those of the age distribution in the population: the foreign school students are underrepresented at the vocational schools. This tendency is even more apparent in the findings of the Institute for Research into the Labor Market and Occupations of the Federal Institution for Labor (Institut für Arbeitsmarkt- und Berufsforschung der Bundesanstalt für Arbeit) for the school year 1976/77 (10). According to these findings, of the 170,600 foreign juveniles between the ages of 15 and 19 who were no longer attending a school of general education, $111,200(65 \%)$ had no professional training whatsoever; $17,200(10.1 \%)$ received some training but without taking a final examination (part-time trade school or basic training year); $42,100(24.7 \%)$ received full job training (fulltime schools 7.1\%; dual system $17.6 \%$ ).

This small selection of data on the quantitative circumstances serves to show that the children and juveniles of aliens are, on one hand, confronted with conditions in the schools and in lessons that do not specifically cater to them and are thus not particularly beneficial. On the other hand, they considerably change the conditions of learning and teaching prevalent in schools. They represent a group which possesses extremely disparate prerequisites for the learning process and which has only scant prospects of successfully finishing school. However, it is not possible for either the schools, teachers, or pupils to accomodate themselves to the situation that has arisen or to expect permanent solutions to the problems that have been identified. For the quantitative situation in this sector changes faster than in other areas of society, the validity of prognoses is questionable, and the effect of measures implemented are in the main uncertain. For example, when the Federal Government ceased recruitment in November 1973, the influx of more foreign workers was hindered and has, in fact, led to a drop in their numbers; but there has not been a 
corresponding decrease in the total number of aliens because, as before, the guestworkers are bringing their families into the country, and recently this has increased. Due to this factor and the relatively high birth rate, the age structure of aliens in the FRG is changing; not only through an upward drift in the "age pyramid" (cf. Fig. 1), but also - and sometimes markedly - through horizontal entries (family reunification) and other fluctuating phenomena.

The children of aliens present problems for schools and schooling for which there are no traditional solutions and for which the institutions and those affected are not prepared. It is astonishing that it was noticed relatively late that within the school system specific problems would arise both because of and for this group of school students, although a glance across the borders of Germany would have been sufficient to ascertain this fact. For example, the Structural Plan for the Educational System of the German Education Board, 1970 , contained plans for up to 1980 but did not deal with the particular school problems of foreign children and juveniles, although in the year it was published there were already nearly three million foreign nationals living in the FRG. Similar cases were the Overall Education Plan of 1973 and the Educational Interim Balance Report of 1976. This is even more surprising considering that, basically, the problem is by no means new for Germany; in 1910, e.g., there were approximately a quarter of a million "Reichsausländer" (settlers from outside the German Empire) - mostly Poles - in NordrheinWesphalia, who in certain districts accounted for over $25 \%$ of the inhabitants. At that time, the school administration at least gave the matter of the schooling of children of these "foreign workers" considerable thought (11). Bingemer et al. are perhaps not incorrect in their interpretation of contemporary German hesitancy in dealing with the problems regarding aliens as psychological suppression of the whole problem complex, arising from the experiences with the approximately 5.5 million forced laborers and 1.5 million prisoners of war who were made to work in Germany during World War II (12).

In the meantime, despite the relatively short time span in which research has been carried out in this field, such a tremendous amount of literature has appeared in German that it is almost impossible to command a view of it. Its contribution to solving the existing problems is unsatisfactory on a number of grounds. For one thing, there is a lack of research which concentrates on the central issues taking the specific circumstances in Germany into account. The findings of research studies conducted abroad have only a limited validity for the situation in the FRG. For example, the type of situation in which children of foreign parents grow up in a new culture is of great importance; also whether 
they belong to the majority or a minority, the future perspectives with which they come, whether their self-image is that of immigrant or "guestworker," and how the residents of the receiving country define their status. On the whole, literature from other countries is concerned with the situation of aliens who explicitly consider themselves immigrants and as a result are in a different situation to that of "guestworkers" from recruitment countries. It was assumed on all sides - including the guestworkers themselves - that their stay in the FRG would be only temporary.

Another problem with many studies published in the FRG is that their authors take up old and trusted themes of research in the social sciences - particularly in sociology and social psychology - and, just as they are, chew them over with regard to the case of the guestworkers. This is a hazardous undertaking, not primarily because of the impending duplication of the social sciences, but because of the curtailment of understanding of the real problem. Thus it is often recommended (without naming the grounds), e.g., that because of the obviously different initial situations of German and foreign children with respect to schooling, we should proceed in a similar way to the old debate over compensatory education for German children from different social classes. High hopes are set on language training programs for small children and school pupils in the dismantling of perceived deficits, for example, or great improvements are expected from merely providing numerous places at the elementary levels. This recommendation overlooks the fact that these children are different from one another in many basic respects and an extremely heterogenous group. Not only do they come from families which, according to the criteria of their country of origin, belong to social classes which cannot be compared to the German lower classes; it has also been suggested that particularly the active and flexible individuals with initiative leave their home countries, which afford them only limited scope for development (13). Insofar as we possess certain knowledge on these matters, their familial constellation, environment, legal position, planning horizons, preconditions and capabilities for learning, etc., are different from those of the group of underprivileged children from German working class families, who are the target group for the development of compensatory educational measures as well as the research that was carried out in this area. In the FRG, the foreign workers and their families often no longer belong to their social class of origin, nor can they be considered as directly belonging to the German lower class (14). 


\section{DIFFERENTIATION ACCORDING TO NATIONALITY}

The simple differentiation between German children and children of foreign parents, as has been made in numerous studies, in the majority of statements on education policy as well as running through the policy measures affecting schools, is as a rule too coarse a distinction and thus unfruitful. In addition to this differentiation, it is much more necessary both in research and in developing measures to improve the situation of these children to make their specifically national characteristics the central focus. To then apply generalizations to another or more nations would represent an independent step.

The differences existing between nations need no substantiation: Turks and Italians differ more in the central aspects of their way of life and outlook than Germans of different social classes do. The practice of different religions alone implies a different relationship to the way of life in Germany, influences reactions to setbacks and frustrations, to uncertainties regarding the future, or to conflicting norms of education in the family and school.

For example, some of these differences are those of the socialization customs and life style in the home country. Of these, surprisingly little is known. There are but few studies on the family in Turkey, Yugoslavia, and Greece. Apart from some impressionistic observations, there are no studies which focus on children growing up under the normal conditions of their home country, on the one hand, and on the other, the kinds of changes and strains introduced by the conditions in Germany and the effect this invasion and the confrontation with other customs and norms has:

On the other hand, differences between the members of different nations arise in Germany. For example, it is of great importance for foreign juveniles regarding the development of their perspective for the future - or even of life in general - as to which country they come from. For families of non-EEC countries, return to their country of origin is effectively to leave Germany forever, as readmittance is not possible. Thus the "threshold" for returning emigrants varies from country to country. This naturally affects the scope for planning, which changes according to the given legal andor political situation. The resultant confusion and uncertainty characteristic of the present situation lead to a severe strain within the family, because the dependence of the children and juveniles on their parents' decisions differs from nationality to nationality (15).

Regarding the possible future perspectives of families, the prognosis of change is difficult to make for other reasons. Should they decide to re-emigrate, 
unemployment will await many who return to their country of origin. However, the situation there and thus the attractiveness of returning can change rapidly; e.g., due to the political discussions of possible membership in the EEC.

Differentiation between nationalities is necessary for other reasons, as in the case of certain behavior characteristics which are not easily detectable but which affect most, if not all, areas of life (16). These range from the national specificity of psychic disturbances among school children (17) to variants of behavioral expectations according to sex in learning style in school, and types of errors when learning German (18) and other subjects, as can be observed in the classroom (19).

These few examples of differences between various nationalities will serve to illustrate that to treat all "foreign children" in the same way can lead to increasing inequalities. The same applies to the productivity of research.

\section{DIFFERENTIATION BETWEEN "GENERATIONS"}

In addition to differentiation according to nationality, at least one other is unavoidable, i.e., that of age, or of the very diverse worlds in which the foreign children find themselves or in which they grew up. It has become usual to speak of "generations" in this connection. It should be noted, however, that this occasions a considerable confusion of terms. For although the immigration of foreign workers has taken place over a matter of decades, it really does constitute an essential difference whether a child grows up in the environment and language of its home country and then has to switch over to another language and environment, or whether from a very early age it grows up in a family subjected to many and varied kinds of strain, needs two languages in order at least to get by, and possibly feels a stranger within the family as well as outside of it.

It will perhaps cause the least confusion if the term "generation" is used in its customary sense, defining generations according to their relative ages and not distinguishing a second from a third generation according to the place where they grew up. Thus the children of the guestworkers are the second generation (20), and there are but few who can be considered as belonging to a third generation, as is apparent from the total number of foreign workers over the last decades: in 1957 there were approximately 100,000 foreign workers, in 1961 the number had increased to half a million, in 1965 to a million, and only in 1971 to two million (21). Even if 15\% illegal immigrants are added to this (22), one cannot yet speak of a generation of grandchildren. 
As mentioned before, the reason for the inconsistent use of the term "generation" was to emphasize the significance of the milieu in which a child grows up. For this reason, I suggest that the second generation be subdivided into a "2nd-H generation" - these the mainly older children and juveniles who were born in the home country, spent their first years there, and then came to Germany to be reunited with their families; and "2nd-D generation" - children that were either born in Germany or came here as babies, who were faced with the problem (and the opportunity) of adapting to the German environment, and who are often not easily identifiable as foreign children.

This differentiation is important both for the selection of a population sample for research purposes as well as for the development of improvement measures, as a visit to any school or kindergarten will demonstrate. The 2nd-D generation differs from the $2 \mathrm{nd}-\mathrm{H}$ not only in their linguistic ability in both languages, but also in the social forms of their contact with adults and other children, and in their readiness to become involved in the way of life and conditions in the FRG. Thus arrival of a large fresh contingent of 2 nd- $\mathrm{H}$ generation in Germany represents a considerable burden for all those concerned with foreign children and juveniles, particularly as the situation has become somewhat easier due to the growing up of greater numbers of the 2nd-D generation.

Of undoubted importance to members of different "generations" is the way they are regarded by the host population and which longer-term perspectives for the future they have to show: whether they consider themselves immigrants or guestworkers, or whether the host population intends to "integrate" them. The concept of "integration" covers a number of different models of varying scope and complexity (23). For example, there is the idea of assimilation, or one-sided integration, i.e., in principle, foreign children should become like German children. In contrast, a pluralist concept of integration envisages a) the German and the various foreign cultures as coexisting side by side unmodified, and b) where there are unavoidable points of conflict, tolerance will be exercised. Finally, the concept of "interactionist integration" foresees mutual influence and association on the basis of equality and equal rights on principle. Further, conceptions of integration affect the intercourse of groups of different nationalities with each other - something which has not been discussed hitherto. For the foreigners often have no experience to fall back on when confronted with persons from other cultural backgrounds but have first to develop these forms, sometimes even despite enmities existing between their different nations. 
The momentary legal position and the length of stay of over five years of the majority of foreign children would normally have led to a standardization of perspectives over the course of the coming years, had there not been the new influx of family members from abroad. Under these circumstances, the exceedingly great heterogeneity among foreign children and juveniles remains a fact that cannot be ignored by research work or educational policy or practical work in schools. Moreover, this area is influenced in a way that is virtually impossible to predict by the political options and the ideas toward "integration" of those involved - whether it signifies pressure to conform and selfabandonment, or tolerated ghettoization, or whether it means the inclusion of the foreign nationals in society, which is then implicitly recognized as a changing and not a static phenomenon.

\section{SCHOOL AND TEACHING PROBLEMS}

From the information given above the following points are of essential importance: a) the high and increasing proportion of children and juveniles of the foreign population as a whole, compared to the German population of the same age; b) the expected increase in the influx of family members, particularly children and juveniles, who grew up in their home countries (2nd-H generation); c) the distribution of young foreigners in the secondary schools, which deviates considerably from that of the German school students; d) the low quota of school certificates; e) the underrepresentation of foreign juveniles in vocational schools; f) the rapid change and thus the difficulty of predicting developments; g) the regional specificity of conditions and their further development.

In order to identify and deal with the school problems of foreign children, the distinction between 2nd- $\mathrm{H}$ and 2nd-D generation is of particular importance. When the children are grouped according to age and length of stay in the FRG, the following can be observed: leaving specific national differences aside Turks particularly are below average with respect to length of stay - in 1978, of children and juveniles up to 20 years old, $30 \%$ were 5 and younger, a further $30 \%$ were 5-10, and the groups of 10-15- and 15-20-year-olds each represented $20 \%$ (24).

Half of the under-fives, in a cautious estimate, can be accounted as 2nd-D generation. Nearly all of this group is within the sphere of familial education, which means that their development is determined by family influences, for example, language learning. On one hand, this represents a relief, for the two cultures in which these children grow up and in which they must operate are 
not as yet in competition. On the other hand, the opportunity of "functionally" growing into German culture is reduced. The situation in which the foreign children spend their first years is probably of essential importance for their later learning capacity. Their basic problem in learning and development is that of having a double "curriculum" to master. They have to find their way in two different cultures whose facets do not always complement one another and sometimes contradict.

In short, for children of foreign parents living in the FRG there are two alternatives in early childhood (and only during that period): either monocultural socialization and later relearning, or bicultural (if not "multicultural") development. A child who grows up within a narrow family unit has both advantages and disadvantages: the advantage of a relatively undisturbed monocultural socialization (25) with possibly better chances of a differentiated intellectual development (26), but with the disadvantage of not only having to learn everything from the very beginning from the point of contact with German culture, but also having to relativize or even substitute many things that have become self-evident in intercourse with the peer group and in order to meet the expectations of adults, if the child is not to remain isolated. By contrast, a child who is at a crèche and kindergarten from the very beginning learns to absorb parts of both cultures and is able to harmonize them (or at least minimize conflicts). Starting school will not appear as a break in development; on the other hand, the child will probably not feel at home in either culture in the differentiated way that a monoculturally-educated child does.

From this, three consequences can be drawn: in the group of under-fives, there will be many children with the same prerequisites as those of the $2 \mathrm{nd}-\mathrm{H}$ generation, even some who were born in the FRG, when they start school. Second, the time of arrival and number of years spent in the FRG provide only a very rough indication of the learning prerequisites with which a child starts school. Thus the school must provide alternatives for the children according to their preschool experience. This implies that lessons must be differentiated and individualized to a hitherto unprecedented extent.

Of the 5-10-year-old group, an estimated $75 \%$ belong to the 2nd-D generation (in the most unfavorable instance, a 10-year-old child would have been in the FRG for four years). Three out of 4 children in this age group are growing up - at least since they reached school age - with the requirement of meeting the demands put upon them by school in Germany and, perhaps even more important, of getting along with German children of their own age every day. Approximately half of the 10-15-year-old group belong to the 2 nd-D 
generation; they have been in the FRG since starting primary school. This probably applies to only about a third of the 15-20-year-old foreign juveniles. At least a quarter of this group has been in Gemany only since the age of puberty, so the majority belong to the $2 \mathrm{nd}-\mathrm{H}$ generation.

Thus, in summary, only a minority of the total of these foreign children can be regarded as belonging to the $2 \mathrm{nd}-\mathrm{H}$ generation, i.e., confronted with the particular difficulties attendant upon scant or no knowledge of the receiving country. However, this group will be de facto larger, mainly because of the close family orientation of the majority of alien families, which in the preschool period can mean almost total isolation from the German language and environment. Should the estimated 700,000 children and juveniles actually join their relations living in the FRG, as is forecast, the proportions will shift still further, and then the majority will effectively belong to the 2 nd- $\mathrm{H}$ generation. Here the so-called horizontal entry throughout the whole school year, according to individual arrival time, represents a severe burden.

\section{THE HETEROGENEITY OF SCHOOLCHILDREN}

In the following, I shall briefly outline selected problems of schoolchildren. I shall not refer in great detail to the considerable body of literature on this subject (27).

Leaving aside the group of foreign children for a moment, a process of increasing heterogeneity among school children can be asserted. In the primary schools, there are several reasons for this (28). A growing number of Bundesländer, for example, have stopped the practice of requiring some children to repeat school years. Also, fewer children are sent to special schools than formerly or diagnosed as too immature to begin schooling for the time being. Further, there has been an increase in the number of children requiring special attention from the teacher; for example, children from broken homes, only children, or children with certain general learning and behavior disturbances. These and other reasons have led to an increased need for individual attention and, thus, to the teacher requiring more time for each child as well as.new forms of teaching and care.

In this increasingly difficult overall situation, which exists even in schools without forreign pupils, those schools with foreign students must experience even greater problems. The foreign children start school with extremely diverse prerequisites, and the heterogeneity thus occasioned is far greater than that existing among German pupils. The significance of the differentiation made above between nationality and "generation" becomes easily comprehensible 
here: children who differ not only from their German school fellows but also from each other with regard to language, cultural norms, curriculum vitae, and previous school career have to be taught and attended to. School achievements and abilities remain in the background due to language deficits, lack of motivation, or other value orientations; specific gender behavior is far more apparent than amongst German pupils, which obliges the teacher to interpret; in contrast to the stated age, it is often impossible to judge the real age of the pupil, which is of course vital for determining the basis of appropriate demands and aid. Added to this is the problem of children who have just arrived joining classes throughout the school year, which often destroys the stability of groups that have just managed laboriously to achieve a certain measure.

A key problem is the different levels of language competency of the foreign workers' children. The difficulties experienced today are far more severe than the language deficits of the German lower classes, which was discussed extensively in the 1960s and 70s. For heuristic purposes, the foreign children can be roughly divided into three groups: a) children who are linguistically competent, do not attract attention in other areas, and are adjusted to conditions in Germany (about $5-10 \%$ of foreign schoolchildren); b) the approximately $40-70 \%$ of foreign children in a school class who obviously have difficulty with the language but are able to follow lessons. These pupils try hard for a long time to keep up in class, but they are doomed to failure if special steps are not taken to help them. The members of this group represent the greatest hindrance for the German pupils during lessons, for they (justly) demand consideration, which necessarily leads to a slower pace in the lessons and occasions many questions concerning language comprehension, mistakes, and misunderstandings. c) The third group consists of children whose difficulties with the language are such that they are unable to follow lessons. This group of children, which is expected to increase considerably, naturally comprises those who have only recently arrived in the FRG. It is worthy of note that the children in this group rarely draw attention to themselves by disruptive behavior but try hard to contribute in spite of almost permanent failure or behave quietly or apathetically.

It is self-evident that a school class of pupils which contains members of all three groups of foreign children described above presents great if not insurmountable problems for the usual frontal teaching method on grounds of language competence alone. It must be emphasized here that scarcely fewer problems exist in teaching classes exclusively made up of foreign children, as their language competency differs so greatly in most cases. Even with groups of 
children of the same nationality, it is likely that the teacher will face more difficulties than if it were a comparable class in the country of origin. Lessons in the children's native language would not solve the problems either, for language competency in the mother tongue cannot be assumed in the case of many children of foreign workers.

In this outline of the special characteristics of foreign children relevant to teaching, reference must be made to their different forms of learning, an area in which no research as yet has been done. At the level of the perception of given signs, symbols, and sounds (for example, when copying from the blackboard, copy drawing, discrimination of sounds) there appear to be processes which are different to those of German pupils first starting school. But a more important observation is that the flexible forms of discourse and the first stages of process-oriented learning that have been used increasingly in German primary schools over the past years, for example, recounting events, such as a birthday party, that happen at home, or projects and open discussions in class, appear strange to many foreign pupils. It appears that they are used to a much more directive approach both at home, in school in their home country (if applicable), in Koran schools, or in specifically national classes. There, more often than in our schools, learning would appear to be guided using straightforward exercises to which there is but one correct answer, thorough preparation and learning prescribed texts by heart. Less emphasis appears to be placed on approaching complex problems by the open question method, to which there is more than one correct answer. This collision of disparate learning and teaching practices necessarily leads to dysfunctional behavior of all concerned. Also, this conflict confronts every teacher with the problem of how far the different prerequisites for learning and expectations of the foreign children should be considered and how far the important steps that have been taken in the German schools should be revoked, in spite of the justified claims of these pupils for individual attention.

This example illustrates the importance of a comprehensive concept capable of guiding practical decisions and conduct for the daily contact and coexistence with foreign children and juveniles. For only a clear answer to the question as to how far the various cultures should adapt to one another can make it possible for teachers and pupils to react with self-confidence in specific situations; i.e., in the example given, either formalizing lessons more (also for the German children) or requiring the foreign children to make an extremely difficult adjustment. In practice, the obvious way out of the difficulty would be the strict individualization of teaching, which would allow each pupil to utilize 
his/her own prerequisites and learning customs, interests, etc. Naturally, this could not be done without appropriate teacher training and the development of new teaching aids. It must be admitted, however, that the question of longterm goal would still be unanswered, for individual teaching could bring about an increasing divergence in the children's development.

With regard to the social behavior of foreign children in school, both informal observations and controlled surveys have found that disruptive behavior in school is expressed differently, namely, less destructively (29). Considering the very high demands on foreign schoolchildren and the unlikelihood of meeting them, refusal or disobedience is seldom. Disturbances in class are freely admitted, if questiond by the teacher; spontaneous cordiality toward teachers and school fellows is often expressed; the equanimity with which excessive demands, frustrations, or even injustice are borne is also striking. Although these are purely observations, one can say that the preconditions for teaching are by no means unfavorable ( 30 ) and the teachers are not additionally taxed by having to deal with rebellious and disobedient students. This applies not only to primary school but also to the lower and upper grades of secondary modern school, where it can happen that the foreign students become the most active class group, so that teachers refuse to let them be transferred to other classes (31). In secondary modern schools, foreign students are often outstanding, a fact that is not really surprising since the largest "pool of talent" at present in our schools is probably to be found in the group of foreign pupils (32).

\section{INSTRUCTION}

Many of the problems with instruction in class are due to the fact that the students have to master a double curriculum and thus have to meet higher demands than their German counterparts. It is not only a question of the strain imposed by having to cope with school lessons as well as specifically national demands on learning, such as Koran school, etc. The excessive demands extend to such essential areas as the mediation required of the individual between contradictory norms and aims. The education of the ability to criticize, as contained in the preamble to German school legislation and thus a duty of the school, is not compatible, for example, with the traditional decisionmaking hierarchy in a Turkish family.

With regard to the school curriculum in a narrower sense, the heavy emphasis on language in our schools has a particularly adverse effect on foreign children. Their language difficulties are probably underestimated in many cases by the teachers, for in the normal classroom situation, statements by foreign 
pupils represent proportionately high linguistic achievements, whereas long periods of silence due to language inability remain unnoticed. In virtually all lessons it can be seen how great the language barrier is: for example, uncomprehending, apparently "stupid" pupils can immediately participate in class after a quick consultation with a teacher who speaks their language. In the long term, the cumulative effect of this language handicap will have severe consequences.

In this connection, too, there are as yet no answers to the problem. For example, should school beginners be taught to write a language, the sound of which they have not been familiar with from an early age and in which they can make the necessary differentiation between sounds only with extreme difficulty? If not, what consequences would a later changeover to the German language, with its different alphabet, entail? What effects are there from cumulative learning deficits in "linear" subjects such as mathematics, where the understanding of a certain content is essential for that which follows? What would be the consequences if, for the sake of full comprehension, subjects were taught in the mother tongue and then followed by repetition of the content in German, as an additional language exercise? Which subjects and aspects could be left out of the curriculum for foreign children so that the workload does not exceed their capabilities?

With regard to the organization of teaching, as pointed out above, foreign children are dependent on individualized learning. A further problem in this connection is that the majority of classes contain only a small group of foreign pupils, often of different nationalities. Approximately half of the school children do not live in urban agglomerations but in towns with less than 100,000 inhabitants. The presence of foreign children in classes represents a trial for the expectations connected with the differentiation and individualization of teaching. As soon as a group becomes too heterogeneous (or is recognized as such), so that the same instruction is not meaningful for all pupils, the teacher is faced with the task of diagnosing the various individual learning prerequisites and then developing appropriate measures. If this is taken seriously, these demands rapidly exceed that which is practicable, so that the teacher is confronted with the alternatives of either relinquishing the basic idea of adequately meeting individual needs, or grouping the pupils in relatively homogeneous units, or giving up direct guidance of the learning process. The results would be: either to continue teaching in the usual way, which presents great difficulties for some of the pupils; or to use forms of extreme differentiation; or to use programmed or computer-assisted instruction or to develop broad, 
many-faceted forms of instruction that are not preprogrammed, i.e., to set up learning situations where those directly involved make the complex discrimination between that which is offered and their own prerequisites to a greater extent, and where they have the freedom to participate in the reorganization of the learning situation, either alone, with other schoolfellows, or with the help of the teacher.

In the area of educational assessment, again only selected, preliminary questions can be outlined here. The traditional method of assessing performance (school reports, marks from 1-6, etc.) has long been considered questionable, even under normal conditions at German schools. With reference to the school problems of foreign children it is totally inadequate. The main problem is that not enough allowance is made for the conditions under which the children have to learn in school. It is thus not only problematical as a judgement on the momentary situation but also cannot be used for prognostic purposes. Here, the arguments employed in the debate in the FRG on reserves of talent, which took place years ago, are particularly applicable: average or even underaverage performance of a child who comes from a background which is not conducive to learning or even hinders it can be an indication of high potential, as this performance takes place under circumstances where such results are extremely improbable.

This fact must also be taken into account not only in giving marks and making school reports but also when using these, for example, in the selection of applicants for a place or job. A juvenile of foreign nationality who manages to attain a final school certificate - even with the worst possible marks - has probably, in the majority of cases, given proof of the mastering of extremely difficult subjects, and it is very likely that favorable prognoses can be deduced as to the further development of such an individual. Justice cannot be done to the foreign school leavers if a simple horizontal comparison of their performance is made with that of their German peers, but this would only be possible if biographical details are also taken into account. Similarly, it is obvious that there must be great flexibility in other areas of educational assessment, e.g., the minimum requirements for starting professional training. These must be redefined when applied to foreign juveniles according to their individual school record and circumstances (33).

Further problems in this field are: a) lack of diagnostic aids for the estimation of functional language competence; b) the separation of diagnosis and treatment: information on performance and performance deficits rarely contains 
recommendations for the next meaningful learning step; c) lack of diagnostic procedures for identifying disturbances in learning ability and behavior, particularly those which are specific to the various groups of foreign children and juveniles. Here also, national specificity must be regarded (34).

As a whole, the influence of school and class instruction must not be overestimated, of course. It is possible that these are of secondary importance compared with familial influences and contact with the peer group - perhaps in some cases of only marginal importance. As an example which may stand for other factors, I should like to draw attention to the role of the parents in families of foreign nationals here. Many of them effectively intervene in the school career of their children - however problematic this may be - in many ways. Many juveniles are taken away from school immediately after the period of compulsory education ends, regardless of exams still to be taken or the child's own wishes. This may be due to economic necessity on the part of the family or fear of excessive alienation. Furthermore, many parents resist the attempts of teachers to include foreign pupils fully in normal classes. Many foreign parents do not seem to be aware that there is a necessity for schoolchildren to be exempted from chores at home in order to do their homework and exercises in their case, an absolutely necessary precondition for continuing participation at school.

While those factors may be at least partially influenced by the school, this is not true concerning the uncertainty as to the future with which many foreign children have to live. The constructive influence of school must be viewed with particular skepsis if the foreign children and juveniles are unable to develop longer-term life and job perspectives, for only then does the effort involved in school work appear meaningful. The possibility of a limited stay as well as little prospect of getting either a job or an apprenticeship are factors which certainly lead to demoralization and lack of motivation, particularly at secondary school, not to mention the possible emergence of delinquent subcultures as a response to the situation (35).

The additional difficulties facing teachers with regard to foreign pupils have been mentioned above. However, as yet only a very small proportion of teachers have prepared themselves for their difficult task, and these mainly on private initiative. Furthermore, very few specific aids are available. Thus, schools and teachers tend to deal with the additional difficulties related to the foreign children in the form of daily "crisis management." It is the exception rather than the rule that the presence of children and juveniles from other 
cultures is regarded as an enrichment. Their presence could be the occasion for changing school and teaching in such a way as to solve the - admittedly very difficult - problems, many of which have been known and discussed for a long time, but which have appeared for the first time in their full acuteness and severity since the advent of the foreign children and juveniles.

Acknowledgements. I wish to express my gratitude to S. Avineri, C. Fried, M. Smith, and A. Zolberg for their very helpful comments; to S. Bernhard for her editorial advice; and to G. Custance for her very competent translation and technical help.

\section{NOTES (See BIBLIOGRAPHY)}

(1) For a comprehensive statistical overview see Trommer and Köhler (1981).

(2) This paper is a revised version of Hopf (1981).

(3) Statistisches Landesamt Berlin II A 82/100.

(4) Calculated from Grund- und Strukturdaten (1982/83), p. 221.

(5) cf. Boos (1978), p. 73f; Hohmann and Stahr (1976), p. 166; and Spies (1979). An example of consequences that cannot be anticipated is the changes in the situation in schools that may result from making the payment of children's allowances dependent on proof of school attendance.

(6) For an account of the complicated and continuously changing legal sifuation of guest workers in Germany see Siewert (1980).

(7) Galculated from Grund- und Strukturdaten (1982/83), and Sekretariat der ständigen Konferenz der Kultusminister (1982).

(8) cf. Boos (1978), p. 3.

(9) Calculated from Grund- und Strukturdaten (1982/83), pp. 27, 55, 221. In the composition of these quotas there are considerable differences between nationalities; cf. Sekretariat d. Kultusministerkonferenz (1982).

(10) cf. Seidel (1979), p. 70.

(11) cf., e.g., Heinemann (1975).

(12) Op. cit. (1970), p. 38. 
(13) Lee (1966) refers to a bimodal distribution of migrants, which comes about through the positive selection of those who react to the positive factors of the target country, and a negative selection of those who react to the negative factors of the country they come from. Sander (1977, p. 176) speaks of a "brain drain" in the countries of origin. For these and similar statements there is as yet no grounded data base, but they do possess a certain plausibility (cf. Geck (1979), p. 136; also see Künne (1979), p. 161f.).

(14) cf. Hoffmann-Nowotny (1973).

(15) cf. Boos et al. (1979), e.g., on the generation conflict in alien families. Of interest in this connection are the recent findings with respect to Berlin, according to which $41 \%$ of the Turks would agree to their sons remaining in the FRG were they themselves to return home (with 13\% refusing); in contrast, the Yugoslavitans and Greeks who gave a positive reply were only $3 \%$ and $2 \%$, respectively (with $64 \%$ and $44 \%$, respectively, refusing); cf. Der Regierende Bürgermeister von Berlin, Dec, 1980, Vol. 1, p. 140f.

(16) cf. Boos (1979), p.62f.

(17) cf. Bayer et al. (1977).

(18) cf. Eideneier (1976); Cimelli and Liebe-Hạrkont (1976); Figge and De Matteis (1976); and Meese et al. (1988),

(19) cf. Hopf, Krappmann, and Scheerer $(19.80)$.

(20) cf. Schrader et al. (1976).

(21) Members of the second generation thus defined pan be of differing ages, according to the age and time of arrival of their parents. The greatest number of people joining their families arrived before recruitment stopped in 1973. Since then, the foreign population has remained roughly constant.

(22) cf. Rist (1978), p. 62.

(23) On the many imprecise concepts used in this connection, see the detailed compilation by Katsarakis (19,74), p. 51f; Esser et al. (1979), p. 5f; and Taft (1953).

(24) cf. Seidel (1979), p. 73. 
(25) cf. the report by G. Franger and J. Vink in ISS Informationsdienst . $2 / 1979$, p. $68 \mathrm{f}$, on problems of growing up in the family, which also draws attention to the discontinuity of even monocultural socialization.

(26) cf. Cummins (1979).

(27) Apart from the specialist journals and periodicals and the usual bibliographic aids, the following are of particular use;

- the information service with respect to foreign nationals of the Institut für Sozialarbeit und Sozialpädagogik, Frankfurt, 1979f;

- the special bibliography compiled by the research group ALPHA, Neuss (cf. Lernen in Deutschland 11/1980, p. 23f); and

- the bibliographies of the Institut für Sozialarbeit und Sozialpädagogik.

(28) cf. Hopf, Krappmann, and Scheerer (1980).

(29) cf., e.g., Bayer et al. (1977).

(30) Mixed classes exhibit fewer problems than classes of only foreign pupils. cf. ibid., p. 509.

(31) Such findings have resulted from research on secondary modern schools carried out by the Max-Planck-Institut für Bildungsforschung (Roeder et al.).

(32) An indirect verification of this can be found in Künne (1979), with regard to the Yugoslavian guest workers (cf. p. 161f and passim).

(33) In connection with this and other aspects, affirmative action, as discussed and practiced in the United States, might be very worthwhile considering (e.g., see Cohen, this volume).

(34) cf. Bayer et al. (1977).

(35) See Albrecht and Pfeiffer (1979). In this connection, ideas derived from programs like MANOF in Israel might be particularly helpful.

\section{BIBLIOGRAPHY}

Albrecht, P.A., and Pfeiffer, C. 1979. Die Kriminalisierung junger Ausländer. Befunde und Reaktionen sozialer Kontrollinstanzen. München: Juventa.

Bayer, W.; Gärtner-Harnach, V.; et al. 1977. Psychologische Untersuchung der Schulsituation der Kinder ausländischer Arbeitnehmer. Abschlußbericht 
der Forschungsgruppe "Kinder ausländischer Arbeitnehmer" an der Fachhochschule für Sozialwesen Mannheim. Mannheim o.J.

Bingemer, K.; Meistermann-Seeger, E; and Neubert, E. 1970. Leben als Gastarbeiter. Geglückte und mißglückte Integration. Köln: Westdeutscher Verlag.

Boos-Nünning, U. 1978. Berufsfindung und Berufsausbildung ausländischer Jugendlicher. Die Darstellung der Schwierigkeiten und Empfehlung zu ihrer Überwindung. Berichte und Materialien der Forschungsgruppe ALFA. Nr. 11. Neuss: Pädagogische Hochschule Rheinland.

Boos-Nünning, U., and Hohmann, M. 1975. Zur Situation deutscher Lehrer von Kindern ausländischer Arbeitnehmer. Ergebnisse einer qualitativen Untersuchung. Bildung und Erziehung 28: 43-52.

Boos-Nünning, U.; Hohmann, M.; Reich, H.; and Kuhs, K. 1979. Materialien zur Fortbildung griechischer Lehrer. Neuss: Publikation ALFA.

Der Regierende Bürgermeister von Berlin (Hrsg.). 1980. Befragung deutscher und ausländischer Haushalte zur Ausländerintegration in Berlin. Vorgelegt von Socialdata, Institut für empirische Sozialforschung. Berlin, Dec. 1980 (2 vols).

Cimilli, N., and Liebe-Harkort, K. 1976. Sprachvergleich Türkisch-Deutsch. Düsseldorf: Schwann.

Cummins, J. 1979. Linguistic interdependence and the educational development of bilingual children. Rev. Educ. Re. 49:-222-251.

Deutscher Bildungsrat (Empfehlungen der Bildungskommission). 1970. Strukturplan für das Bildungswesen. Bonn: Bundesdruckerei.

Eideneier, H. 1976. Sprachvergleich Griechisch-Deutsch (Publikation ALFA). Düsseldorf: Schwann.

Esser, H.; Gaugler, E.; Neumann, K.-H.; et al. 1979. Arbeitsmigration und Integration. Sozialwissenschaftliche Grundlagen. Materialien zur Arbeitsmigration und Ausländerbeschäftigung, vol. 4. Königstein: Hanstein.

Figge, E., and de Matteis, M. 1976. Sprachvergleich Italienisch-Deutsch. Düsseldorf: Schwann.

Geck, H.-M. 1979. Die griechische Arbeitsmigration. Eine Analyse ihrer Ursache und Wirkung. Königstein: Hanstein. 
Griese, H.M. 1981. Jugendliche Gastarbeiterkinder: Situation und Problematik. Eine Literatur- und Forschungsdiskussion. Zeitschrift für Pädagogik 26: 441-456.

Heinemann, M. 1975. Die Assimilation fremdsprachlicher Schulkinder durch die Volksschule in Preußen seit 1880. Bildung und Erziehung 28: 53-69.

Hoffmann-Nowotny, H.-J. 1973. Soziologie des Fremdarbeiterproblems. Eine theoretische und empirische Analyse am Beispiel der Schweiz. Stuttgart: Ferdinand Enke.

Hohmann, M., and Stahr, I. 1976. Ausländische Schüler an allgemeinbildenden Schulen in Nordrhein-Westfalen. Daten und Analysen. Pädagogische Rundschau 30: 165-182.

Hopf, D. 1981. Schulprobleme der Ausländerkinder. Zeitschrift für Pädagogik 27 (6): 839-861.

Hopf, D.; Krappmann, L.; and Scheerer, H. 1980. Aktuelle Probleme der Grundschule. In Max-Planck-Institut für Bildungsforschung, Arbeitsgruppe Bildungsbericht (Hrsg.). Bildung in der Bundesrepublik Deutschland. Daten und Analysen, vol. 2, p. 1113-1176. Stuttgart, Klett/Reinbek: Rowohlt.

Katsarakis, N. 1974. Probleme kultureller und gesellschaftlicher Integration griechischer Arbeitnehmer in der BRD. Exemplare Untersuchung im Bereich des Freizeitverhaltens. Dissertation, University of Aachen.

Kühn, H. 1979. Stand und Weiterentwicklung der Integration der ausländischen Arbeitnehmer und ihrer Familien in der Bundesrepublik Deutschland. Bonn, September 1979: Memorandum des Beauftragten der Bundesregierung.

Künne, W. 1979. Die Außenwanderung jugoslawischer Arbeitskräfte. Ein Beitrag zur Analyse internationaler Arbeitskräftewanderungen. Königstein: Hanstein.

Lee, E.S. 1966. A theory of migration. Demography 3: 47-57.

Meisel, J.M. 1978. Emigratión sí - Einwanderung, nein! In Wuppertaler Arbeitspapiere zur Sprachwissenschaft 1: 1-37.

Ministerium für Arbeit, Gesundheit und Sozialordnung Baden-Württemberg. 1979. Viele Ausländer wollen in Baden-Württemberg bleiben. Stuttgart: Materialdienst Ausländische Mitbürger in Baden-Württemberg.

Rist, R.C. 1978. Guestworkers in Germany. The Prospects for Pluralism. New York: Praeger. 
Roeder, P.M. 1979. Kompensatorischer Sprachunterricht. In Lexikon zum Deutschunterricht, E. Nündel, ed., p.178-196. München: Urban und Schwarzenberg.

Sander, A. 1977. Entgegnung zu Schmidtke, H.-P. Ausländerkinder und Sonderschule. Zeitschrift für Heilpädagogik 28: p. 176-180.

Schmidtke, H.-P. 1977. Ausländerkinder und Sonderschule. Zeitschrift für Heilpädagogik 28: 170-175.

Schrader, A.; Nikles, B.W.; and Griese, H.M. 1976. Die zweite Generation. Sozialisation und Akkulturation ausländischer Kinder in der Bundesrepublik. Kronberg: Athenäum.

Seidel, H. 1979. Ausländische Arbeitnehmer in der Bundesrepublik Deutschland: Ein statistischer Überblick. Deutsch lernen 1: 52-76.

Sekretariat der ständigen Konferenz der Kultusminister der Länder in der Bundesrepublik Deutschland. Ausländische Schüler in der Bundesrepublik Deutschland 1970 bis 1981. Bonn, August 1982.

Senat von Berlin, June 1978. Bericht zur Lage der Ausländer in Berlin.

Siewert, P. 1980. Zur Entwicklung der Gastarbeiterpolitik und der schulpolitischen Abstimmung der Kultusministerkonferenz. In Bildung in der Bundesrepublik Deutschland. Daten und Analysen. Max-Planck-Institut für Bildungsforschung, Arbeitsgruppe Bildungsbericht (Hrsg.). Stuttgart: Klett/Reinbek: Rowohlt.

Spies, U. 1979. Ausländer in Berlin (West) 1972 bis 1977. Analyse der altersstrukturellen Entwicklung der ausländischen Bevölkerung aus Anwerbestaaten. Berliner Statistik 33 (2): 33-42.

Statistisches Landesamt Berlin. 1976. Zur Entwicklung der im Grund- und Hauptschulaiter stehenden ausländischen Kinder in den Bezirken von Berlin (West). Berliner Statistik 30 (7): 174-184.

Taft, R. 1953. The frame of reference concept applied to the assimilation of immigrants. Hum. Relat. 6: 45-55.

Trommer, L., and Köhler, H. 1981. Ausländer in der Bundesrepublik Deutschland. Dokumentation und Analyse amtlicher Statistiken. München: Deutsches Jugendinstitut. 